\title{
Gambaran Status Gingivitis Pengguna Alat Ortodontik Cekat
}

\author{
(Gingivitis Status on Fixed Orthodontic Appliance Patients)
}

\section{Shulchan Ardiansyah, Megawati Prajarini}

Program Studi Kedokteran Gigi Fakultas Kedokteran dan Ilmu Kesehatan Universitas Muhammadiyah Yogyakarta

\begin{abstract}
Abstrak
Ortodontik merupakan salah satu perawatan gigi yang bertujuan untuk memperbaiki posisi gigi geligi. Pada pasien pengguna alat ortodontik cekat memiliki peningkatan akumulasi plak karena terjadi pula peningkatan kesulitan dalam menghilangkan plak pada alat ortodontik cekat, sehingga resiko terjadinya gingivitis akan meningkat pada pasien pengguna alat ortodontik cekat. Penelitian bertujuan untuk mengetahui gambaran status gingivitis pada mahasiswa kedokteran dan kesehatan tahun pertama yang menggunakan alat ortodontik cekat. Metode statistik yang digunakan untuk menganalisa data penelitian ini adalah metode uji analisa data deskriptif. Indeks pengukuran yang digunakan pada penelitian ini adalah indeks gingiva Loe dan Silness (Gingivval Index). Hasil yang didapatkan pada penelitian ini adalah $89 \%$ mahasiswi tahun pertama yang menggunakan alat ortodontik cekat memiliki status gingivitis dengan kriteria gingivitis ringan.
\end{abstract}

Kata Kunci : Alat Ortodontik Cekat, Gingivitis, Ortodontik

\begin{abstract}
Orthodontic is one of the dental treatment that has a purpose to repair the position of teeth. For patient who wears fixed orthodontic appliance will have an enhancement of accumulation of plaque which caused by the diffulty of removing the plaque it self, with the result that higher risk of gingivitis may occur in patient using fixed orthodontic appliance. The purpose of this study is to give an overview of gingivitis in first year students of medical and health faculty who used fixed orthodontic appliance. Statistic method which is applied to analyze this study is descriptive data analysis test method. Index measurement that is used in this study is gingiva Loe and Silness Index (Gingivval Index). The result from this study is $89 \%$ of student who used fixed orthodontic appliance having lower risk of gingivitis criteria.
\end{abstract}

Keywords : Fixed orthodontic appliances, Gingivitis, Orthodontic,

Korespondensi (Correspondence) : M. Shulchan Ardiansyah, Universitas Muhammadiyah Yogyakarta, Yogyakarta, email : shulchan@yahoo.com

Tujuan umum dari perawatan ortodontik adalah untuk memperbaiki kehidupan pasien dengan cara meningkatkan fungsi gigi dan rahang dan estetika dentofacial.' Tujuan utama perawatan ortodontik adalah untuk mencegah atau memperbaiki maloklusi yang jika tidak diperbaiki akan mengakibatkan permasalahan maloklusi semakin kompleks pada gigi permanen atau dapat mengakibatkan anomali skeletal. ${ }^{2}$ Keadaan gigi yang mengalami maloklusi dapat mengakibatkan bentuk wajah menjadi kurang baik atau mengganggu estetik, baik pada waktu menutup mulut, berbicara, atau tertawa. ${ }^{3}$ Ortodontik ini terbagi menjadi dua, yaitu ortodontik lepasan (removable) dan ortodontik cekat (fixed). Ortodontik lepasan ini menggunakan alat yang lebih sederhana dan lebih mudah pemasangannya sehingga pasien bisa melepas dan memasangnya sendiri. Alat cekat mempunyai konstruksi yang komplek, terdiri dari komponen aktif lengkung (arch wire), section wire, dan auxillaris serta komponen aktif berupa band, bracket, dan tube. ${ }^{4}$ Penelitian terdahulu mengatakan bahwa perawatan ortodontik dapat mengubah lingkungan di dalam rongga mulut yaitu meningkatkan rangsangan laju saliva, kapasitas buffer dan $\mathrm{pH}$ saliva. ${ }^{5}$ Disamping itu memicu terjadinya penumpukan plak yang terdapat pada permukaan gigi sehingga akan meningkatkan terjadinya inflamasi. 5

Menurut Suproyo (2009), terdapat bahaya yang mungkin ditimbulkan selama perawatan ortodontik, diantaranya adalah asbses periodontal, iritasi akibat band ortodontik, terjadi resorpsi akar karena terdapat tekanan yang kuat, adanya retensi plak sehingga dapat menyebabkan gingivitis, dan dapat menyebabkan perlukaan pada gingiva. Alat ortodontik cekat ini berpotensi menyebabkan gingivitis dan bisa menjadi periodontitis, terutama selama pergerakan intrusive dan tipping. Hal ini dikarenakan kantong gingiva yang semakin dalam ketika terdapat gerakan tipping dan intrusive. 2,6 Keadaan gingivitis disebabkan oleh akumulasi plak yang mengandung bakteri karena adanya faktor lokal seperti desain gigi tiruan atau alat ortodontik yang tidak baik, kalkulus, gigi berjejal, kebiasaan bernafas melalui mulut, tambalan yang berlebih, permukaan tambalan yang kasar, serta karena karies yang terdapat pada daerah proksimal atau servikal. ${ }^{7}$

Penelitian mengenai status kebersihan mulut pengguna alat ortodontik cekat (OHI-S) pada siswa sekolah menengah atas pernah dilakukan sebelumnya yaitu terdapat 36 responden tergolong pada status kebersihan mulut sedang. ${ }^{8}$ Sedangkan peneliti ingin 
mengetahui gambaran status gingivitis pengguna alat ortodontik cekat pada mahasiswa kedokteran gigi.

\section{METODE PENELITIAN}

Desain penelitian yang digunakan pada penelitian ini adalah metode observasional deskriptif. Populasi pada penelitian ini adalah seluruh mahasiswi tahun pertama FKIK UMY yang sedang menjalani perawatan ortodontik dengan penggunaan alat ortodontik cekat. Penentuan sampel pada penelitian menggunakan metode total sampling. Pemeriksaan status gingivitis menggunakan pengukuran indeks gingiva Loe dan Silness (Gingivval Index). Gingival Index (GI) merupakan indeks yang berkembang untuk menilai tingkat keparahan gingivitis dan lokasinya pada 4 daerah pemeriksaan yaitu papilla disto fasial, tepi fasial, papilla mesiofasial, dan seluruh tepi gingiva bagian lingual. Skor indeks gingiva tiap gigi adalah skor tiap gigi dijumlahkan kemudia dibagi 4. Jika skor indeks gingiva tiap individu didapatkan dari jumlah skor tiap gigi kemudian dibagi dengan jumlah gigi yang diperiksa. Kriteria skor $0,1-1,0$ termasuk gingivitis ringan, $1,1-2,0$ dikatakan gingivitis sedang, dan 2,1 - 3,0 terdapat pada kriteria gingivitis parah. 6

\section{HASIL PENELITIAN}

Subyek penelitian berjumlah 100 orang., terdiri dari 57 orang (57\%) merupakan mahasiswi Program Studi Pendidikan Dokter (PSPD), 24 orang (24\%) adalah mahasiswi Program Studi Pendidikan Dokter Gigi (PSPDG), 10 orang (10\%) merupakan mahasiswi Program Studi Farmasi (PSF), dari 9 orang (9\%) merupakan mahasiswi Program Studi IImu Keperawatan (PSIK). Berdasarkan distribusi karakteristik jenis kelamin (tabel 1) jumlah subyek penelitian seluruhnya adalah perempuan.

Tabel 1. Distribusi Jenis Kelamin Subyek Penelitian

\begin{tabular}{lll}
\hline Jenis Kelamin & Jumlah & Presentase (\%) \\
\hline Perempuan & 100 & 100 \\
Laki-laki & 0 & 0 \\
\hline
\end{tabular}

Data pada tabel 2 menunjukkan bahwa paling banyak mahasiswi dengan umur 19 tahun (70 \%) dan paling sedikit dengan umur 18 tahun (vCXz \%). Rentang usia pada subyek penelitian ini adalah umur 18 tahun sampai umur 20 tahun.

Tabel 2. Distribusi Umur Subyek Penelitian

\begin{tabular}{|c|c|c|}
\hline Umur & Jumlah & $\begin{array}{c}\text { Presentase } \\
(\%)\end{array}$ \\
\hline 18 & 8 & 8 \\
\hline 19 & 70 & 70 \\
\hline 20 & 22 & 22 \\
\hline
\end{tabular}

tertera pada tabel 3 dikatakan bahwa $86 \%$ subyek penelitian telah menggunakan alat ortodontik cekat lebih dari 6 bulan.

Tabel 3. Lama Penggunaan Alat Ortodontik Cekat

\begin{tabular}{ccc}
\hline Lama Penggunaan & Jumlah & Presentase (\%) \\
\hline 6 bulan & 14 & 14 \\
Lebih dari 6 & 86 & 86 \\
bulan & & \\
\hline
\end{tabular}

Distribusi status gingivitis dapat dibedakan berdasarkan kriteria gingivitis ringan, gingivitis sedang, dan gingivitis parah. Hasil penelitian mengatakan bahwa sebagian besar pengguna alat ortodontik cekat mengalami gingivitis ringan yaitu sebanyak $89 \%$ atau bisa dikatakan bahwa sebanyak 89 orang dari 100 sampel yang ada mengalami gingivitis ringan, sebanyak 3 orang atau $3 \%$ memiliki kriteria gingivitis sedang, dan sisanya sebanyak 8 orang atau $8 \%$ memiliki kriteria normal pada status gingivitisnya.

Tabel 4. Distribusi Status Gingivitis Mahasiswa PSPDG FKIK UMY

\begin{tabular}{lcc}
\hline \multicolumn{1}{c}{ Kriteria } & Jumlah & Presentase (\%) \\
\hline Normal & 8 & 8 \\
Gingivitis Ringan & 89 & 89 \\
Gingivitis Sedang & 3 & 3 \\
Gingivitis Parah & 0 & 0 \\
\hline
\end{tabular}

\section{PEMBAHASAN}

Berdasarkan hasil penelitian pada Tabel 1. didapatkan bahwa jenis kelamin subyek penelitian adalah $100 \%$ perempuan. Hal ini dikarenakan oleh salah satu faktor predisposisi dari gingivitis merupakan kebiasaan merokok. Kriteria inklusi peneliti disebutkan bahwa pasien atau subyek penelitian tidak mempunyai kebiasaan merokok. Asap panas rokok yang berhembus terus menerus akan mengakibatkan sekresi saliva berkurang dan keadaan rongga mulut menjadi kering sehingga menyebabkan penumpukan plak. Plak mempunyai 3 komponen fungsional yaitu organisme kariogenik, organisme penyebab kelainan periodontal khususnya Bacteroides asaccha rolyticus (gingivitis) dan Actinobacillus, serta bahan adjuvan dan supresif.9 Berdasarkan uraian di atas dapat dikatakan bahwa orang yang mempunyai kebiasaan merokok mempunyai resiko terena penyakit periodontal lebih besar dibandingkan dengan orang yang tidak mempunyai kebiasaan merokok.

Berdasarkan hasil penelitian yang di dapat pada Tabel 2. didapatkan informasi bahwa subyek penelitian pada penelitan ini berusia 18 tahun sampai 20 tahun. Di usia ini biasanya manusia sudah sadar akan kepentingan estetisnya sehingga di kelompok usia ini terdapat banyak orang yang menggunakan alat ortodontik cekat. Berdasarkan hasil pada Tabel 3. didapatkan bahwa semua subyek telah memakai alat 
ortodontik cekat lebih dari sama dengan 6 bulan. Hal ini terkait dalam kriteria inklusi penelitian ini bahwa lama pemakaian alat ortodontik cekat pada subyek minimal 6 bulan. Keadaan gingivitis dapat terjadi kemungkinan secara meyeluruh dari ringan hingga pada pengguna alat ortodontik cekat setelah 6 minggu pemasangan. ${ }^{10}$ Sumber lain juga menyebutkan bahwa pergeseran gigi geligi akan terjadi setelah 6 bulan pemakaian alat ortodontik cekat.

Berdasarkan hasil pada tabel 4. didapatkan informasi bahwa hampir semua subyek penelitian mengalami kondisi gingivitis ringan. Pada tabel disebukan bahwa hanya 8\% mahasiswi tahun pertama pengguna alat ortodontik cekat yang mempunyai keadaan gingiva dengan kriteria normal dan $3 \%$ mahasiswi tahun pertama pengguna alat ortodontik cekat yang mempunyai keadaan gingiva dengan kriteria sedang. Sedangkan $89 \%$ subyek penelitian memiliki status gingivitis dengan kriteria gingivitis ringan. Pada populasi mahasiswi tahun pertama tidak terdapat subyek yang mengalami gingivitis berat, hal ini kemugkinan bisa terjadi karena subyek penelitian mempunyai tingkat kesadaran yang tinggi.

Faktor yang dapat mempengaruhi keadaan gingiva seseorang salah satunya adalah faktor plak. Faktor lain yang mempunyai pengaruh besar terhadap gingiva adalah faktor tekanan yang berlebih pada gigi oleh alat ortodontik cekat, faktor tersebut juga menjadi salah satu faktor yang penting. Alat ortodontik cekat mempunyai potensi yang mengakibatkan gingivitis terutama dalam pergerakan gigi intrusive dan tipping. ${ }^{2}$ Hal ini dikarenakan kedua pergerakan tersebut mengakibatkan gigi bergerak ke arah dalam sehingga menekan soket gingiva dan menyebabkan gingivitis.

Berdasarkan hasil dari penelitian yang telah dilakukan oleh peneliti, maka dapat disimpulkan yaitu sebanyak 89 orang dari 100 orang (89\%) mahasiswi tahun pertama di Fakultas Kedokteran dan IImu Kesehatan yang menggunakan alat ortodontik cekat memiliki status gingivitis dengan kriteria gingivitis ringan; dan faktor plak dan faktor tekanan yang berlebih merupakan penyebab utama dari keadaan gingivitis. Banyak faktor yang sulit dikendalikan dan dapat mempengaruhi terbentuknya plak, seperti cara menggosok gigi, frekuensi menggosok gigi, konsumsi makanan, serta susunan gigi geligi maupun perilaku dari subyek penelitian.

\section{DAFTAR PUSTAKA}

1. Graber M. Vanarshdall RL. Orthodontics current principles and techniques. $3^{\text {rd }}$ ed. Missouri: Mosby. 2000, 4: 394-413

2. Bishara SE. Textbook of Orthodontics. Philadelphia: W.B Sounders Company. 2001.

3. Dika DD, Hamid T, Silvia M. Penggunaan Index of Orthodontic Treatment Need (IOTN) sebagai evaluasi hasil perawatan dengan peranti lepasan. Orthodontic dental jurnal. 2011, 2(1): 45-8.

4. Foster TD. BukU ajar Ortodonti. Ahli Bahasa : Lilian Yuwono. Edisi 3. Jakarta : EGC. 1997.

5. Lara CE. Montiel BNM. Sánchez PL. Alanís TJ. Effect of orthodontic treatment on saliva, plaque and the levels of Streptococcus mutans and Lactobacillus. Med Oral Patol Oral Cir Bucal. 2010 Nov $1 ; 15(6): e 924-9$.

6. Suproyo H. Penatalaksanaan Penyakit Jaringan Periodontal. cetakan 1. Yogyakarta. Kanwa Publisher. 2009: 35.

7. Galag CJR, Anadita PS, Waworuntu O. Status Kebersihan Mulut pada Pengguna Alat Ortodonti Cekat Berdasarkan Oral Hygine Index Simplified di Sekolah Menengah Atas Negeri 1 Manado. Jurnal e-Gigi (eG). 2015, 3(2): 298-301.

8. Usri K. Eriska R. Tenny S.D. Nunung R. Asep J.A. Dudi A. Irman S. Diagnosis \& Terapi Penyakit Gigi dan Mulut. Edisi 2. Bandung : LSKI (Lembaga Studi Kesehatan Indonesia), 2012.

9. Singh G. Textbook of orthodontics. 2nd ed. New Delhi: Jaypee Brother Medical Publisher Ltd. 2007: 68-9, 90-1.

10. Roeslan BO. Imunologi Oral Kelainan di dalam Rongga Mulut. FKUI. Jakarta, 2020 